Eneau, J. (2017). From self-directed learning to self-formation: transforming the self through Bildung. In A. Laros, T. Fuhr \& E.W. Taylor (Eds). Transformative Learning meets Bildung. An international exchange (pp. 165-178). Rotterdam (NL): Sense Publishers (Translation: Kate Davis.)

\title{
FROM SELF-DIRECTED LEARNING TO SELF- FORMATION: TRANSFORMING THE SELF THROUGH BILDUNG?
}

\author{
A French Approach to the Notions of Formation and Transformation
}

\author{
JEROME ENEAU \\ CREAD - RENNES 2
}

\section{INTRODUCTION}

Work on Transformative Learning and Bildung remains little known and utilized in France, yet there is another emancipatory tradition of adult education, one that is both "developmental and existential" and that connects self-education, or self-formation (autoformation in French), to development of adult autonomy.

This perspective is based on a humanist approach to education, aiming at emancipation and stipulating that adult education is first and foremost a process of formation of the self and development of one's autonomy, by the learner him/herself first and also with and through others, thanks to the resources in the environment. However, this developmental process calls into question both the modalities and the purpose of adult education. The process that some French-language researchers refer to as "autoformation" has no real equivalent in English-language literature. At the same time, this French tradition has a number of points in common with Transformative Learning and German Bildung.

Through a brief examination of the French tradition, we propose to study this approach, its parallels to TL and Bildung as well as its uniqueness in French research. This chapter presents, in three sections, first the roots and the particularities of autoformation which unlike North American work on self-directed learning favors an "integral" view of autonomy aiming for emancipation of the adult. The second section presents its connections to and differences from the two schools of thought, Bildung and Transformative Learning. The last section stresses possible paths for research that could be done to strengthen these ties.

\section{SELF-FORMATION VS SELF-DIRECTED LEARNING}

The French school of "autoformation" ("self-formation" in this text) is distinct from the traditions in English speaking countries, particularly the area of Self-Directed Learning, in several ways. Its roots are in a humanism that grew out of the Enlightenment. It is tied to the ideas of autonomization and emancipation, and also has developmental and existential, even political, dimensions. Thus, work on self-formation remains relatively separate from work on self-directed learning as it is dealt with in English-language research (Carré, Moisan \& Poisson, 1997; 2010).

Eneau, J. (2017). From self-directed learning to self-formation: transforming the self through Bildung. In A. Laros, T. Fuhr \& E.W. Taylor (Eds). Transformative Learning meets Bildung. An international exchange (pp. 165-178). Rotterdam (NL): Sense Publishers (Translation: Kate Davis). 


\section{A French Tradition in Adult Education}

The seminal works on adult education in France are rooted in the traditions of the Enlightenment found in the Encyclopedistes and Condorcet's Project. During the French Revolution, Condorcet $(1791 / 2005 ; 1792)$ introduced in his Project for public instruction (Condorcet, 1792) the inalienable right of every individual to have access to education throughout life, including a "second chance" for people who had not been able to continue studying or to access the initial training that they had wished. Adult education in this project is seen as the possibility to continue instruction throughout one's entire life (Condorcet, 1791/2005, pp. 26-27, pp. 43-44), through weekly and monthly conferences, particularly "in order to ensure that men [sic], at every age of life, can retain the knowledge they have already acquired and to learn more" (Condorcet, 1792). The ultimate purpose of Condorcet's Project was to remove the barriers that existed between the classes of the time, the end of the $18^{\text {th }}$ century, "the class of men [sic] who reason and the class of those who believe, the class of masters and the class of slaves" (Condorcet, 1792).

It was not until two centuries later with the Law on Professional Continuing Education, passed in 1971, that this right was instituted in France not only as a possibility for every person to have continuous education (therefore a right), but also as an obligation, for employers, to finance this education (therefore a responsibility). Out of this lengthy gestation, several particularities of the French context of research on and practices in adult education were born: a focus on the term "formation", which today still continues to refer specifically to adults (while the term "éducation" connotes the period of instruction and learning for children); the idea of a universal right, for adults, to access learning as part of their professional occupation (including especially those who were not afforded the opportunity during their "initial instruction"); lastly, a strong axiological anchoring of this vision of education (formation) as the possibility to "think for oneself", as Kant expressed it, that fits, in the goals of autonomy and emancipation, the French humanist tradition of adult education (Eneau, 2008, 2012a).

\section{Autonomization and Emancipation}

Of course, as is the case in most Western countries, due to the strong political and socioeconomic pressures weighing on the worlds of work and education today, this approach and these values are being challenged heavily (Barros, 2012; Wildemeersch \& Olesen, 2012). Despite that, both research and practice remain solidly grounded in this vision and the French school of self-formation (autoformation), for the majority, refers to it.

It often retains a meaning of comprehensive adult development sometimes qualified as "complete self-formation" (autoformation intégrale), the adjective serving to highlight the fact that adult education cannot be reduced to skills, ways of learning or tools for managing one's own learning, but rather that this perspective includes a comprehensive view of the human being in the process of constructing him/herself.

Autoformation is particularly visible in research on autodidacts, for example, as well as in the claims and the debates concerning the conception of autonomy that underpins work in the field. Similar to the way in which Candy (1991) himself stressed the role of autonomy in self-directed learning, a number of ambiguities remain concerning the role and the purpose of this autonomy, as a "predisposition", as a "process" or as a "product" of learning in adulthood (Taylor, 2006; Eneau, 2012a). In work published in French, autonomization of the adult remains the point of departure, the process and the purpose of learning and it supposes an acquisition of a "procedural" autonomy (related to the capacity to learn by oneself, particularly in cognitive terms, i.e. by selecting the methods, tools, styles or preferences for learning) and also an "epistemological" autonomy (related to the ability to think for oneself and to think about oneself, i.e. an adult as an autonomous, free, responsible citizen).

\section{2}

Eneau, J. (2017). From self-directed learning to self-formation: transforming the self through Bildung. In A. Laros, T. Fuhr \& E.W. Taylor (Eds). Transformative Learning meets Bildung. An international exchange (pp. 165-178). Rotterdam (NL): Sense Publishers (Translation: Kate Davis). 
However, autonomization, understood as a developmental process that is constantly created and renewed throughout life, has a number of points and several presuppositions in common with research on self-directed learning (Carré, Moisan \& Poisson, 1997; 2010). Often called in the French literature an existential and developmental perspective it was theorized on an epistemological and methodological level by an entire school of thought in the 1970s and 80s, focused around adult education researchers such as Boutinet, Fabre, Labelle and Pineau (Eneau, 2008). It is not possible here to go into detail about what this French segment of the field has brought to adult education research. We will merely highlight a few important characteristics of the work these "founding fathers" accomplished. This includes their humanist vision of education (sharing Knowles' postulates in North America and those of the nascent field of andragogy); the constructivist approach of development, connecting learning to a relationship to others and the surrounding world (and joining in, from a psychological point of view, a constructivist, post-Piagetian approach and encouraging a complex, systematic approach); and the focus placed on the responsibility and the right to education for adults who are able to learn and shape themselves (se former) throughout life (in the context of the 1971 French law, bringing Condorcet's Project into the current day).

Even more particularly, in research from the late $20^{\text {th }}$ century, this perspective of selfformation retains a significant connection to the French history of adult education and the purpose of emancipation that it implies. Similar to yet distinct from research in other countries that have a heritage of popular education, worker education or critical pedagogy (Wiggins, 2011; Kokkos, 2012), adult education in France is deeply connected to this emancipatory ideal. This is true even if, for the founding fathers of self-formation in its social dimension, this type of continuing education remains focused on social advancement and personal development now made possible for everyone, at every age in life, and particularly for the most underprivileged portions of the population. The issue then, to use Labelle's expression (1996, p. 172), is “conquering one's own autonomy" to emancipate oneself in order to escape subjugation and dependence. This aim is not an illusory quest for total freedom or complete independence but a way to access a new form of "autonomy in interdependence", which here is consciously chosen (Eneau, 2014).

Self-formation, in French, retains strong connections to the political ideal of emancipation, given that the term refers directly to the values of the Enlightenment, the French Revolution and Condorcet's Project promoting the ideals of liberty, equality in education and full enjoyment of citizenship. It is in this perspective too that the term remains close to the term autonomy, as it was developed following Kant, to mean a capacity "to think and act for oneself", without being dependent on teaching, the thoughts or the will of another, allowing each person, as another founding father, Dumazedier, put it, "to learn to forego the imposed master" (1993, p. 10).

\section{Self-Education or Self-Formation?}

The first difficulty in distinguishing this approach from other adult education traditions comes from the etymology of the terms and the choice made by Pineau, and by the followers of the Tours School in particular, to talk about self-formation (autoformation), rather than self-education (auto-education) or self-directed learning (apprentissage autodirigé) (Eneau, 2008). This choice was made with reference to the roots of the term formation.

The lexical field of formation, in French often reduces the vocabulary to the idea of training (vocational training, professional training, etc.), when it comes to skill acquisition for adults. The reverse is true for the word éducation, often used in the broadest sense and to mean in general all kinds of education, for children or concerning life-long learning. However the linguistic roots of the French verb former are very close to the Latin term formare and its use dates back further in French than the use of the term éduquer ("to educate", from educare) (Rey, 2004, p. 1189); its roots recalls the verb's original meaning

Eneau, J. (2017). From self-directed learning to self-formation: transforming the self through Bildung. In A. Laros, T. Fuhr \& E.W. Taylor (Eds). Transformative Learning meets Bildung. An international exchange (pp. 165-178). Rotterdam (NL): Sense Publishers (Translation: Kate Davis). 
of "to shape", "to arrange" and later "to instruct" (Rey, 2004, pp. 1460-1463). It was only in modern times that the semantic core shifted from "to create, bring into existence (give shape)" to "to organize (create the form)". Its etymology contains the idea of creation (God shaped or formed man in his image) and this divine attribution (God as the original creator) is also found in the idealized philosophical purpose of education - to continue the divine mission, it is a duty for human beings to "shape themselves" (se former) and to "give form to the self", throughout their lives (Rey, 2004, p. 1462-1463). The connections to the German language term of Bildung are obvious, the latter term having a clear relationship to the ideas of image, form and creation, including in a spiritual sense (Schneider, 2012, pp. 303-304).

Consequently, it is in light of the history of the vocabulary that we must understand the use in contemporary language of the term "self-formation" (autoformation), which literally highlights the capacity that every human has to work continually on "his/her own form", to develop him/herself over a lifetime. It is through this ideal meaning that the existential, developmental perspective on self-formation in France retains a charged axiological dimension. It is also this epistemological dimension that reveals in self-formation's purpose, a goal of autonomization rather than emancipation, in the critical or social sense of the term, which it has retained in other traditions, such as in Freirean-inspired pedagogy. But it is also to avoid these same semantic ambiguities in the French term autoformation, that the English translation "self-education" is sometimes preferred over "self-formation". While the more literal translation "self-formation" is closer to the original meaning of Bildung, it is further apart from the meaning of self-directed learning. In particular it does not stop at functional or operational aspects of learning, but supposes a capacity for selfdevelopment and the ability to create the self and direct one's own life.

\section{SELF-FORMATION, BILDUNG AND TRANSFORMATIVE LEARNING}

While the tradition of self-formation does not totally overlap with that of self-directed learning, this French work does have some points in common with the English adult development literature (Hoare, 2006) and at least to some degree with research that examines the concept of autonomy in the developmental perspective of self-directed learning (Taylor, 2006). However, in the French tradition, the developmental vision of learning in adulthood remains imbued with a social dimension that makes clear the connections to and differences with Bildung and Transformative Learning.

\section{A Developmental Approach to Adult Education}

On a psychological level, French self-formation's developmental and existential approach is based on a certain number of constructivist principles, a "constructive-developmental orientation" as Taylor stresses (2006, p. 215), and for a more "progressive" and "positive" vision of adult development, similar to the way Kegan $(1982,1994)$ uses different stages of development in a post-Piagetian perspective (Boutinet, 2004; Hoare, 2006; Taylor, 2000; Taylor 2006). Beyond the autonomy, maturity and wisdom this orientation shares another idea with work on self-directed learning, the idea that "the autonomy of self-authorizing knower is not a separation, but rather of a new kind of connection" (Taylor, 2006, p. 215). It relates self-formation to a socio-constructivist perspective on learning rather than a cognitive-constructivist one, in the Piagetian sense. Finally, the leading role of experience and reflection, which aims to make the implicit explicit, turn experience into knowledge and transform learning into development of the "identity" and "personality" (Hoare, 2006), is common to all of these works (Boutinet, 2004).

However, this does not mean that this existential and developmental approach shares all of North-American developmental psychology's presuppositions, particularly the work of Kegan, whom English-language authors refer to most often. While the different aspects of the "psychological self" (cognitive, affective, interpersonal and intrapersonal) can be agreed to, the developmental helix that Kegan (1982, p. 109) proposed has been partly

4

Eneau, J. (2017). From self-directed learning to self-formation: transforming the self through Bildung. In A. Laros, T. Fuhr \& E.W. Taylor (Eds). Transformative Learning meets Bildung. An international exchange (pp. 165-178). Rotterdam (NL): Sense Publishers (Translation: Kate Davis). 
called into question. Much research from even before Piaget's death in 1980 has criticized the idealistic vision proposed by his stage approach. In particular are concerns about development of adults, given that for adults even more than for children, in a world that is shaped first and foremost by modalities of socialization that, from an interpersonal, affective and social point of view, over determine learning in its intrapersonal dimensions. Additionally, the presupposed "universality" of Piaget's developmental vision was also strongly called into question (Boutinet, 2004).

Several changes allow us to understand why it has been called into question in the French adult education tradition. As shown in previous research (Eneau, 2008), the first one comes from personalist philosophy (Mounier), which arose in France in the 1950s, and through existentialism (Sartre) and the contributions of French phenomenology (MerleauPonty). This "personalist perspective" (Eneau, 2008) supports the primacy of the "person" over the "individual" and the primacy of interpersonal relationships over the construction of the self (Eneau 2008; Ricoeur, 1996). This philosophical approach of the person creating him/herself first and foremost with and through others (the person in this sense is "more" than simply an individual) can explain in part the clear preference among adult education theorists in France for Vygotsky's psychological model over Piaget's.

The second change came later in the form of postmodernism (Lyotard) and the revival of French criticism (Bourdieu) from a psychological and a sociological point of view (Koller, 2003; Boutinet, 2004). At the turn of the 1980s (Lyotard's work The Postmodern Condition was published originally in French in 1979), this movement used the critique of communicational civilization to call into question the relationship to knowledge, to denounce the reproduction of social domination and to view the changes in adult life from a new angle, with all the alterations required in a world guided by flexibility, mobility and adaptability. From then on, adult development has been seen less as a continuous and intrapersonal process than as a method of permanent adaptation to clashes, constraints and opportunities coming from outside (Boutinet, 2004; Boltanski, 2009).

The third change is due to the success in France that research focusing on a "complex" approach to education and transformation processes experienced from the 1980s and 90s; using ideas of self-organization, multi-referentiality, cross-disciplinarity and complexity (Alhadeff-Jones, 2012) it attempts to connect with a renewed epistemological ambition. This last approach has made possible, on the social epistemology level this time, a break with the contributive disciplines of psychology and sociology in particular, which education sciences had heavily drawn from up until then, making it possible to examine the question of adult education, autonomization, and transformation with new conceptual tools.

\section{Self-formation, Between a Developmental and a Social Approach}

We are aware of Kegan's relationship to the post-Piagetians' developmental perspective and how he distanced himself from the postmodern approach in particular (Kegan, 1994, 2000). Despite that, these contributions influenced the classical, universalist vision of adult education and development, in Continental research at least in two ways: a) in its relationships to Bildung, questioned by the postmodern observation of a "radical plurality" imposed on adults in the contemporary world (Koller, 2003), and b) in the contributions of feminist research that favored a more "relationist" vision of autonomy (Mezirow, 2000; Boutinet, 2004; Jouan \& Laugier 2009; Eneau, 2012b). It is this relationist vision, sometimes referred to as "constructionist", that is favored in research on educational reciprocity (Labelle, 1996). In this perspective, it is the relationship to others that determines adult development rather than the other way around.

A social (relational, interpersonal) approach to autonomy supposes that the process of adult self-formation concerns a dual movement towards integration and differentiation at the same time. A development social psychology describes as a process of "identization" (as "identity construction"), particularly for adolescents and young adults, a sort of double, synchronous movement towards identification and differentiation that brings together the 
process of autonomization and the process of identization (Tap, 1991). This calls into question Kegan's affirmation that "differentiation always precedes integration" (Kegan, 1994, p. 326). Instead it encourages us to relate work on self-formation to research examining development of personality and identity (Hoare, 2006), particularly from a social psychological point of view, or even to relate it to research and practices interested in social and critical dimensions of transformative learning (Brookfield, 2000; 2009).

Despite that, we cannot help but noticing that this more social and interactionist approach to adult education and adult autonomy development has been little examined in French research (Carré, Moisan \& Poisson, 1997; 2010). Similarly, we also note the tenuous connections that have been established in French-language research with work on Transformative Learning, even less in France than in other countries in Europe (and in Greece in particular, see Kokkos, 2012). We cannot fail to note that an approach focusing on relationships would gain from being compared to the recent work on transformative learning that has come out of different cultural milieus and different geographical areas, much of which highlights the importance of social and relational dimension in the process of transformation (Taylor \& Snyder, 2012).

On the other hand, closer to the epistemological dimension of self-directed learning, the French perspective on self-formation and the role of autonomy in adult development are similar to the critical dimension addressed by some North-American researchers who see the ability to think for oneself as the ultimate purpose of adult education. Mezirow reminds us that "in adulthood, informed decisions require not only awareness of the source: context of our knowledge, values, and feelings but also critical reflection on the validity of their assumptions or premises" (Mezirow, 2000, p. 7). And, while recognizing Kegan's contribution and the concept of "epistemological development", Mezirow concludes: "The goal of adult education is to help the learner develop the requisite learning processes to think and choose with more reliable insight, to become a more autonomous learner" (2000, p. 348).

In the ultimate goal of autonomization there are a number of similarities between selfformation, in French research, the constructive-developmental approach (Kegan, 2000) and transformative learning (Mezirow, 2000, 2009), particularly it aims at self-authorizing and self-transforming that are assumed by epistemology's centrality to the process of "reforming our meaning-forming" (Kegan, 2000, p. 52). As Taylor points out (2006, p. 203), this process of "trans-form-action" makes it possible to connect the "significant experiences" as sources of destabilization and learning (in the Piagetian process of equilibration between assimilation/accommodation) in Kegan's work (1982) and the "disorienting dilemmas" cited by Mezirow (2000) in speaking of transformative learning (Taylor 2006, p. 211).

Yet, beyond this epistemological proximity, the French perspective on self-formation takes its distance from what is often perceived as a very "pragmatic" vision of NorthAmerican self-directed learning. From the French existentialist point of view, autonomy created within interdependence, that develops with and through others, privileges the connections and the meaning that the learner attributes to this form of interdependence (both in language and in action), which only allows the development of autonomy if and when this interdependence is consciously acknowledged and accepted. Therefore, the influence of personalist, existentialist and postmodern thought has led self-formation in France to take some critical distance from the question of "how" in favor of the question "why". Kegan recognizes that the predominance of "how" over "what", which is necessary for childhood education is not enough for adults (Kegan, 1994, pp. 273-275). Learning that is truly transformative, from an epistemological point of view, also aims to question the purpose of the autonomy that is being constructed, allowing the responses to "for whom" and "for what" to take shape (Mezirow, 2012; Taylor \& Snyder, 2012). international exchange (pp. 165-178). Rotterdam (NL): Sense Publishers (Translation: Kate Davis). 


\section{Social Self-Formation and Bildung}

Moving away from the classical vision of developmental psychology, postmodernism's critical contributions, and more generally, the revival of continental philosophy through to the contribution of the "linguistic turn" (Ricoeur, 1996) have made it possible to see the similarities in the axiological vision of self-formation in the French tradition and the questions that Koller (2003) raises concerning Bildung.

Following on from Lyotard, Koller affirms that "to link is necessary; how to link is contingent" (Koller, 2003, p. 158). Even if Koller highlights the predominance of the link thanks to linguistic analysis' contributions to postmodern thought, he also stresses the predominance of these links over the contingencies of the relationship. Even more importantly, as in Ricoeur's work on identity (1996), Koller stresses that with Lyotard and his questions ("by whom", "for whom", "what" and "what about") we see a revival of Bildung thought through philosophy of language, which is essential to the movement. There is also a questioning of the heritage of educational philosophy which since Rousseau has given the individual (the subject) a privileged place, and a restoration of the importance of language, similar to Humboldt's view of Bildung, where language is part of the construction and sharing of knowledge even beyond the construction of the experience. Lastly, in the same way that Ricoeur and the personalists in France contributed a dual ethical and political dimension (Eneau, 2008, 2012a) to the reflection on adult education through both the role of language and the role of action, Koller (2003) highlights how postmodernism's contributions lead us to question the universality of the process of Bildung (formation). Beyond the regime of plurality that encourages imagining different modalities of Bildung (all possible Bildungen, in its plural form) these contributions also reintroduce ethical and political dimensions to the reflection on the aims of adult education (Koller, 2003; Wahlström, 2010).

And it is likely in this epistemological and axiological sense that we can establish parallels between the French tradition of self-formation and research on Bildung. As much work has shown, in so much as they share the primacy of experience and action and hold up the importance of communication over instrumentalization, these perspectives with their dual ethical and political aim both raise the question of democracy. This is why Fabre $(1994,2014)$ and Wahlström (2010) borrow from the German Bildung tradition, as well as from Dewey, the experiential (on the personal level) and political (on the citizenship level) contributions of a certain vision of experience as a lever for autonomization and emancipation from "routine", the "habits of the mind" or from "frames of reference", to use Mezirow's terms (2000). The connections are even closer between the French perspective (Labelle, 1996) and the German tradition (Schneider, 2012), when we consider in both traditions how "experiences" (plural) form "experience" (singular), when "an experience" (in the sense of what one lives through) turns into "experienced" (in the existential sense) (Labelle, 1996), in the tradition of Fichte or Hegel, joined by Schneider (2012).

There remain some distinctions between the two perspectives, German and French respectively. Bildung, on the one hand, deals with dimensions that are not included in selfformation, in the existential and developmental perspective, with regards to ambiguous relations to "alienation" that this school of thought presupposes (Schneider, 2012). The French tradition preserves a focused aim of emancipation. Additionally, within Bildung, there is a learner's perception of his/her own limitations while the French vision retains the aim of educability and autonomization which it sees as always possible (Labelle, 1996; Schneider, 2012). Conversely, the perception of Bildung in France is less visible (or perhaps consigned to a vision that is labeled old-fashioned) than in German research, where it has been recently reexamined in consideration of the question of "what self should be shaped?" On the French side, we often limit ourselves to looking at the double role of experience, seen as "an acquired capacity to solve problems" (its cumulative, instrumental aspect) and as "an attempt to give meaning to a test" (its integrating, hermeneutic aspect), which Boutinet (2004) for example relates to Erfahrung and Erlebnis, borrowed from 
Gadamer. Yet one of the ambiguities that remains in French research about how to interpret Bildung likely comes from a lingering doubt about the role of the innate and the acquired in this perspective. Because it is a process of "creating the self", the interpretation most often given in French literature is the aim for the learner of "finding his/her own form", or "to recognize who he/she is", in the way that the meeting of the self through meeting others, through travel, discovery and exploration of the world (Delory-Momberger, 2001, 2002), probably doesn't sufficiently take into consideration the absence of telos or the development of innate aptitudes that Bildung, in its original sense, goes beyond (Schneider, 2012).

\section{FROM BILDUNGS INFLUENCE TO A REVIVAL OF CRITIQUE?}

Finally, French research, despite its sometimes simplified borrowings from German Bildung, is also fed by a critical tradition different from that of the North-American transformative perspective and thus opens different paths to explore these similarities and differences.

First, with regards to Bildung, self-formation's developmental and existential perspective insists on the esthetic dimension that comes with any consideration, in French, of "form" and more generally of the creative dynamic that the ideas of formation or Bildung imply in their very etymology (Wunenburger, 1993; Fabre, 1994, 2014). Thus, as Kegan (2000) stresses, there are likely several areas that could be considered in greater depth with regards to the various ways that "form transforms", between the dual process of dynamic architecture of "that form which transforms" (i.e. the "form of knowing") on the one hand and the dynamic architecture of "reforming our forms of knowing" (i.e. "the psychological process of transformations in our knowing") on the other hand. From this point of view, research in adult developmental psychology could gain from being more closely examined in comparison to North-American research in the field. At the same time, North-American research could also learn from a more interactionist, even socio-constructivist vision taken from social psychology, dealing in particular with the process of autonomization and identization in a more "empathic" and "relationist" perspective of autonomy and selfformation (Jouan \& Laugier, 2009; Eneau, 2012b; Taylor \& Snyder, 2012; Taylor \& Cranton, 2013). As "postmodern" and "critical" studies have shown, like feminist and gender studies, what's important now is distinguishing this adult development from postPiagetian work - the multiple "identity tensions" today lead us to organize our modes of existence in a world of "ubiquitous adulthood" and to see our identities in their plurality, leading us to combine individuation and socialization, constant construction of our personality and ceaseless reconstruction of the different facets of our identities (Boutinet, 2004). In that sense, these approaches question more than the role of experience and the reflective work it brings about, they question a truly "transformative perspective" in the way Mezirow sees it, which provides, from a French point of view, "an alternative perspective that complements the developmental option" (Boutinet, 2004, p. 27), but one that is still little known and not widely available, even less so in French translation, and therefore rarely used by French researchers.

In terms of critical positioning, the postmodernist heritage is an invitation to question the observed "identity deficit", the lack of professional activity and the deficiency of social connections (Boutinet, 2004) as well as a denial of recognition (Honneth, 2007) which are today characteristics of the limits of the development possible in adulthood for a growing number of people. The existential and developmental approach of course has connections to biological, psychological and social dimensions as well as to economic, cultural and political aspects that call into question the universality of the principle of education that is thought to be "good for everyone". If identities today are in transformation, they are also "composite identities" created from multiple membership. Lyotard said there is no longer a substantial "I", there are identities, transformations that waver within the dialectic of same and different in an age of mobility, remediation, tension and constant identity reconstruction (Boutinet, 2004). From there, the processes of constant individualization (in 8

Eneau, J. (2017). From self-directed learning to self-formation: transforming the self through Bildung. In A. Laros, T. Fuhr \& E.W. Taylor (Eds). Transformative Learning meets Bildung. An international exchange (pp. 165-178). Rotterdam (NL): Sense Publishers (Translation: Kate Davis). 
training, at work, personal evaluation, the necessity of plans or projects) also result from a continual process of "self maximization" that should be examined. The tradition of French social critique (Foucault and Bourdieu, in particular) can join contemporary critical approaches, Honneth (2007) for the German school and Boltanski (2009) for the French, which reexamine the demand for recognition and the processes of emancipation in movements that are decidedly different but possibly complementary (Eneau, 2014).

The revitalized humanist hopes for autonomization and emancipation will probably require the following: a closer examination of the possible contributions from these social philosophers who combine concern for the self with concern for others, social criticism and the possibility to transform oneself and the world. The transformative perspective makes it possible to consider not only changes in the individual but in a broader sense, the values and ideals that an autonomous adult who is a responsible citizen has the right and the duty to call into question in order to give meaning to his/her life and our coexistence. Meanwhile, the Bildung tradition reminds us that the final goal of education, as Condorcet, Lindeman, Dewey or Whitehead already pointed out in their time, is the continual (and current) need to (re)construct democracy (Mezirow, 2012, p. 91).

\section{REFERENCES}

Alhadeff-Jones, M. (2012). Transformative learning and the challenges of complexity. In E.W. Taylor \& P. Cranton (and ass.). The handbook of Transformative Learning. Theory, research, and practice (pp. 178-194). San Francisco (CA): Jossey-Bass.

Barros, R. (2012). From lifelong education to lifelong learning. Discussion of some effects of today's neoliberal policies. European Journal for Research on the Education and Learning of Adults, 3(2), 119-134.

Boltanski, L. (2009). De la critique. Précis de sociologie de l'émancipation. Paris : Gallimard.

Boutinet J.-P. (2004). Que savons-nous sur cet adulte qui part en formation ? Note de Synthèse. Savoirs n 4, p. 9-49.

Brookfield, S. (2000). Transformative learning as ideology critique. In J. Mezirow (and ass.) (2000). Learning as transformation. Critical perspectives on a theory in progress (pp. 125-148). San Francisco (CA): Jossey Bass.

Brookfield, S. (2009). Engaging critical reflection in corporate America. In J. Mezirow \& E.W. Taylor (2009). Transformative learning in practice. Insights form community, workplace and higher education (pp. 125-135). San Francisco (CA): Jossey Bass.

Candy, P.C. (1991). Self-direction for lifelong learning: a comprehensive guide to theory and practice. San Francisco: JosseyBass.

Carré P., Moisan A., \& Poisson D. (dir.) (1997). L'autoformation : psychopédagogie, ingénierie, sociologie. Paris : Presses Universitaires de France.

Carré P., Moisan A., \& Poisson D. (dir.) (2010). L'autoformation : perspectives de recherche. Paris : Presses Universitaires de France.

Cranton, P., \& Taylor, E.W. (2012). Transformative learning theory. Seeking a more unified theory. In E.W. Taylor \& P. Cranton (and ass.). The handbook of Transformative Learning. Theory, research, and practice (pp. 3-20). San Francisco (CA): JosseyBass.

Castoriadis, C. (1978/1999). Les Carrefours du labyrinthe (6 tomes). Paris : Seuil/Points.

Condorcet N. de (1791/2005). Cinq mémoires sur l'instruction publique. Retrieved from: http://classiques.uqac.ca/classiques/condorcet/cinq memoires instruction/cinq memoires.html

Condorcet, N. de (1792). Rapport et projet de décret relatifs à l'organisation générale de l'instruction publique. Présentation à l'Assemblée législative des 20 et 21 avril 1792. Retrieved from: http://www.assemblee-nationale.fr/histoire/7ed.asp

Delory-Momberger, C. (2001). Bildung et écologie humaine: de la Philosophie de la Nature à la pédagogie de l'environnement. Education permanente, $\mathrm{n}^{\circ} 148,45-56$

Delory-Momberger, C. (2002). Bildung et récit de vie. Chemins de formation, ${ }^{\circ} 4,13-23$

Dewey, J. (1939/1976). Creative democracy: The task before us ( $1^{\text {st }}$ edition 1939). In J. Boydston (Ed.). John Dewey: The later works, 1925-1953. Vol. 14 (pp. 224-230). Carbondale: Southern Illinois University Press.

Dumazedier, J. (1993). Pour une sociologie de l'autoformation permanente. Lyon : Se Former.

Dumazedier, J., \& Leselbaum, N. (1993). Émergence d'un nouveau secteur des sciences de l'éducation : la sociologie de l'autoformation. Revue française de pédagogie, $\mathrm{n}^{\circ} 102$, 5-16.

Eneau, J. (2008). From autonomy to reciprocity, or vice-versa? French Personalism's contribution to a new perspective on selfdirected learning, Adult Education Quarterly vol. 58, $\mathrm{n}^{\circ}$ 3, 229-248.

Eneau, J. (2012a). Educational reciprocity and developing learner autonomy: the social dimension of self-directed learning. In K. Schneider (dir.) Becoming Oneself: Dimensions of "Bildung” and the Facilitation of Personality Development (pp. 29-54) Wiesbaden (Allemagne) : VS Verlag.

Eneau, J. (2012b). Apprenant adulte et processus d'autoformation. Les dimensions sociales de l'autonomie en formation. Note de Synthèse présentée en vue de l'obtention de l'Habilitation à Diriger des Recherches (unpublished dissertation). Rennes: Université de Rennes 2.

Eneau, J. (2017). From self-directed learning to self-formation: transforming the self through Bildung. In A. Laros, T. Fuhr \& E.W. Taylor (Eds). Transformative Learning meets Bildung. An international exchange (pp. 165-178). Rotterdam (NL): Sense Publishers (Translation: Kate Davis). 


\section{JEROME ENEAU}

Eneau, J. (2014). Emancipation. In A. Jorro (dir.). Dictionnaire des concepts de la professionnalisation. Bruxelles : De Boeck. English, L. M. (dir.) (2005). International Encyclopedia of Adult Education. New York: Palgrave Macmillan.

Fabre, M. (1994). Penser la formation. Paris : Presses Universitaires de France.

Fabre, M. (2014). La question de la forme en éducation. Education Permanente, ${ }^{\circ} 199$.

Freire, P. (1974). Pédagogie des opprimés. Conscientisation et révolution. Paris : Maspero.

Hoare, C. (2006). Work as catalyst of reciprocal adult development and learning: identity and personality. In C. Hoare (ed.). Handbook of adult development and learning (pp. 344-380). New York (NY): Oxford University Press.

Honneth, A. (2007). La lutte pour la reconnaissance (1 ${ }^{\mathrm{e} r e}$ édition 1992). Paris : Cerf.

Jouan, M. \& Laugier, S. (2009). Comment penser l'autonomie ? Entre compétences et dépendances. Paris : Presses Universitaires de France.

Kegan, R. (1982). The evolving self. Problem and process in human development. Cambridge (MA). Harvard University Press.

Kegan, R. (1994). In and over our heads. The mental demands of modern life. Cambridge (MA): Harvard University Press.

Kegan, R. (2000). What "form" transforms? A constructive-develpemental approach to Transformative learning. In J. Mezirow (and ass.) (2000). Learning as transformation. Critical perspectives on a theory in progress (pp. 35-69). San Francisco (CA): Jossey Bass.

Kokkos, A. (2012). Transformative learning in Europe. An overview of the theoretical perspectives. In E.W. Taylor \& P. Cranton (and ass.). The handbook of Transformative Learning. Theory, research, and practice (pp. 289-303). San Francisco (CA): Jossey-Bass.

Koller, H.C. (2003). Bildung and radical plurality: towards a redefinition of Bildung with reference to J.F. Lyotard. Educational Philosophy and Theory, vol. $35, \mathrm{n}^{\circ} 2,155-165$.

Labelle, J. M. (1996). La réciprocité éducative. Paris : Presses Universitaires de France.

Mezirow, J. (2009). Transformative Learning Theory. In J. Mezirow \& E.W. Taylor (2009). Transformative learning in practice. Insights form community, workplace and higher education (pp. 19-31). San Francisco (CA): Jossey Bass.

Mezirow, J. (and ass.) (1990). Fostering critical reflection in adulthood. A guide to transformative and emancipatory learning. San Francisco (CA): Jossey Bass.

Mezirow, J. (and ass.) (2000). Learning as transformation. Critical perspectives on a theory in progress. San Francisco (CA): Jossey Bass.

Mezirow, J., \& Taylor, E.W. (2009). Transformative learning in practice. Insights form community, workplace and higher education. San Francisco (CA): Jossey Bass.

Mezirow, J. (2012). Learning to think like an adult. Core concepts of Transformation Theory. In E.W. Taylor \& P. Cranton (and ass.). The handbook of Transformative Learning. Theory, research, and practice (pp. 73-95). San Francisco (CA): JosseyBass

Rey, A. (dir.) (2004). Dictionnaire historique de la langue française. Paris : Dictionnaires Le Robert.

Ricœur, P. (1996). Soi-même comme un autre. Paris : Seuil.

Schneider, K. (2012). The subject-object transformations and 'Bildung'. Educational Philosophy and Theory, vol. $44 \mathrm{n}^{\circ}$ 3, $302-$ 311.

Tap, P. (dir.) (1991). La socialisation de l'enfance à l'adolescence. Socialisation et construction de l'identité personnelle, Paris: Presses Universitaires de France.

Taylor, E.W. (2009). Fostering transformative learning. In J. Mezirow \& E.W. Taylor (2009). Transformative learning in practice. Insights form community, workplace and higher education (pp. 3-17). San Francisco (CA): Jossey Bass.

Taylor, E.W., \& Cranton, P. (2013). A theory in progress? Issues in transformative learning theory. RELA, vol. 4, n ${ }^{\circ}$, 33-47.

Taylor, E.W., \& Snyder, M.J. (2012). A critical review of research on transformative learning theory, 2006-2010. In E.W. Taylor \& P. Cranton (and ass.). The handbook of Transformative Learning. Theory, research, and practice (pp. 37-55). San Francisco (CA): Jossey-Bass.

Taylor, K. (2000). Teaching with developmental intention. In J. Mezirow (and ass.) (2000). Learning as transformation. Critical perspectives on a theory in progress (pp. 151-180). San Francisco (CA): Jossey Bass.

Taylor, K. (2006). Autonomy and self-directed learning: a developmental journey. In C. Hoare (ed.). Handbook of adult development and learning (pp. 196-218). New York (NY): Oxford University Press.

Wahlström, N. (2010). Do we need to talk to each other? How the concept of experience can contribute to an understanding of Bildung and democracy. Educational Philosophy and Theory, vol. 42 n³, 293-309.

Wiggins, N. (2011). Critical pedagogy and popular education: towards a unity of theory and practice. Studies in the Education of Adults, Vol. 43, n $1,34-49$

Wildemeersch, D., \& Olesen, H.S. (2012). The effects of policies for the education and learning of adults - from 'adult education' to 'lifelong learning', from 'emancipation' to 'empowerment'. European Journal for Research on the Education and Learning of Adults, 3(2), 97-101.

Wunenburger, J.J. (1993). La Bildung ou l'imagination dans l'éducation. In R. Bouveresse (dir.). Éducation et philosophie: écrits en l'honneur d'Olivier Reboul (pp. 59-70). Paris: Presses Universitaires de France.

Eneau, J. (2017). From self-directed learning to self-formation: transforming the self through Bildung. In A. Laros, T. Fuhr \& E.W. Taylor (Eds). Transformative Learning meets Bildung. An international exchange (pp. 165-178). Rotterdam (NL): Sense Publishers (Translation: Kate Davis). 